\title{
The Iglu and the Tent: Centring the Northern Voice in Mathematics Teaching
}

\author{
Fok-Shuen Leung \\ University of British Columbia
}

\section{Author's Note}

This work was inspired by conversations with a community of practice based at Nunavut Arctic College in Iqaluit, including Andrea Burry, Maryse Cohen, Goota Jaw, Kaviq Kaluraq, and Gloria Uluqsi. The author gratefully acknowledges their contributions, as well as the indispensable contribution of the land itself.

\begin{abstract}
We outline the broad epistemic tendencies of Inuit and Qallunaaq ${ }^{1}$ teaching, in the context of a faculty member in the Mathematics department of a large, research-oriented Qallunaaq university. We argue that, against the recommendations of academic literature, historical support and personal experience, the South maintains a position of strong cultural assertiveness. Finally, we propose two shifts in position that centre the Inuit voice which are aimed at protecting the North and learning from it.
\end{abstract}

Keywords: Inuit; mathematics education 


\title{
The Iglu and the Tent: Centring the Northern Voice in Mathematics Teaching
}

\begin{abstract}
I don't know exactly what the year was but I was about 6-7 years old. We had to move to Pond Inlet from Mount Herodier. A teacher came down to our camp and told us that we had to go to school... We ended up in a tent near the river...Our grandpa in the winter would try to pick up some cardboard boxes and put them around and inside the tent, and when we had enough snow, he would build an iglu around the tent to keep us warm. ${ }^{2}$
\end{abstract}

-Apphia Kiliktee (Qikiqtani Inuit Association, 2013, pp. 27-28)

\section{Epistemic Tendencies}

In Pond Inlet, Nunavut, the Inuktitut term that corresponds roughly to the month of March is Ikiaqpavvik, meaning "when the sun is higher in the sky but still not too high." The term used in Igloolik is Avunniit, "when premature baby seals are born." The same term is used in Arviat, but refers to caribou calves, not seals (Oosten \& Laugrand, 2017). These are descriptions, not etymologies; if the calves are born earlier in Arviat one year, Avunniit arrives sooner.

Local, deeply grounded relationships traditionally characterize knowledge and knowledge transfer in the Inuit communities of Nunavut. Experience is considered to be a prerequisite to knowledge, and context, a prerequisite to instruction. For that reason, the most honoured mode of teaching is storytelling by elders.

Saullu Nakasuk, an elder from Pangnirtung Bay, described the importance of experience in this exchange from an interview with students from Nunavut Arctic College: 'I'm only telling you about what I've experienced. I'm not going to tell you about anything I haven't experienced... Even if it's something I know about, if I haven't experienced it, I'm not going to tell about it" (Oosten \& Laugrand, 2017, p. 6).

In Samuel Johnson's recounting of Boyle, testimony is an arrow shot from a long bow; "the force of it depends on the strength of the hand that draws it" (Bloom, 1986, p. 375). In contrast, argument, whose force is undiminished by its source, is an arrow shot from a crossbow. In the Inuit tradition, learning is about long bows, not crossbows. As the interviewer Alexina Kublu ( as cited in Oosten \& Laugrand, 2017) writes in her introduction to interviews of elders:

As each one has his or her own knowledge, it is absolutely essential to view this knowledge as related only to that particular elder. Once the source-more specifically, the name of the elder-is lost, the knowledge loses its roots and becomes devoid of much value to most Inuit (p. 13).

On the face of it, this is difficult to reconcile with Southern, or Qallunaaq, education, perhaps especially with Qallunaaq mathematics education.Mathematics itself, at least in the Qallunaaq canon, inclines toward the general, not the particular. It is important that the Pythagorean theorem is true for all planar right triangles, whether in $21^{\text {st }}$ century Vancouver or in ancient Samos. The theorem's value derives from its universality, not from Pythagoras himself.

In this regard, Qallunaaq mathematics education tracks mathematics, at least in practice. Instructional strategies are acclaimed if they can be demonstrated to be widely applicable. 
Teacher effect is acknowledged, but as something to be controlled for: "best practices" are the ones that achieve positive results despite teacher effect. This partiality for the general over the particular colours everyday conversations about teaching: "The problem with active learning," we hear in the faculty lounge, "is that it requires a special kind of teacher." It affects the tools of our trade. To construct a short assignment for a first-year university calculus class, for example, we might consult the list of learning objectives, look at assignments from previous versions of the course, select questions from an online repository of questions like WeBWorK, ${ }^{3}$ and then post the assignment link on the class webpage where it will be accessed and graded automatically. These instruments - objectives, online question banks, automatic grading-all work because they save the duplication of efforts from instructor to instructor, and from one year to the next.

In short, where Inuit education has a local presupposition, Qallunaaq education has a global bias. The tendency of Inuit education is to scale down, and the tendency of Qallunaaq education is to scale up.

\section{Academic, Historical and Personal Perspectives}

The Inuit tendency is better.

The academic literature is unambiguous: mathematics teaching is ideally active (Freeman et al., 2014), cooperative (Duncan \& Dick, 2000), student-centred (Walczyk \& Ramsey, 2003) and small-scale (Tajima, 1998). Teachers matter significantly: instructor effect is not a bug, but a rich feature (Chetty, Friedman, \& Rockoff, 2014; Gershenson, 2016; Hill, Blazar, \& Lynch, 2015).

The historical literature also favours the small and local over the large and global. While the relationship between the modern Qallunaaq educational system and the demands of industry may be overstated (Watters, 2015), there is little doubt that the invention or persistence of the modern educational system's large-scale features is driven primarily by the pressure to teach more, not to teach better. The medieval university lecture in which rare books were read aloud to a group of students, was, in the absence of any copying technology beyond manual transcription, both innovative and empowering (Willinsky, 2018). The persistence of the lecture today is equivocal at best, and the best arguments in its defense are narrowly logistical (Bligh, 1972). Logistics also figure heavily in arguments for automatic grading, multi-section courses, even multiple-choice exams. Only a modern university would need to invent a computerized academic advisor (Laghari, 2014; Siegfried, Wittenstein, \& Sharma, 2003).

Finally, our own experiences as university faculty members confirm what the research literature and the historical signposts suggest: large scale teaching is essentially concessionary. We teach small classes when we can, and large classes when we must; we scale down when we are allowed to, and scale up when we are forced to. There is a wide range of pedagogical settings for university math courses; and generally, the teaching that is most personally important to usgraduate mentoring, research seminars, upper-year Honours classes - takes place in the smallest, most personal settings. We may recognize that it is impossible for first-year students in "service courses" to be taught in these settings, but the reverse - to make graduate supervision more like teaching a large, centrally driven, multi-section course - is so plainly undesirable that it is never considered, except under duress. 


\section{Assertiveness and Advantages}

Why then, despite the recommendations of academic research, historical guidance and personal experience, do we in the South favour the Qallunaaq model over the Inuit one? Overwhelming logistical pressure may be the ostensible reason, but it is not the complete story.

If it were the complete story, we would expect the stance of the Qallunaaq educator towards the Inuit educator to be slightly sheepish - the pose of someone who has something to learn. This may be the case at the level of individuals, but not at the level of institutions. Institutionally, all the assertiveness is in the South. Qallunaaq universities are the ones that host programs to improve education in Indigenous communities (Alberta Education, 2012). Qallunaaq researchers write papers on how Indigenous students can successfully navigate the borders between their "home culture" and "school culture" (Aikenhead \& Huntley, 1999). Indigenous teachers go to Qallunaaq universities to be trained, and then return to their communities, presumably equipped with something new and valuable. These actions and systems are supported by the best intentions, but the flow of information is understood to be predominantly in one direction. The default assumption-which, to their enormous credit, authors such as Aikenhead and Huntley (1999) carefully acknowledge (p. 160) —is that the Qallunaaq model has something special to offer.

In contrast, consider Finland. ${ }^{4}$ The Qallunaaq pose is deferential towards the Finnish educational model (Lombardi, 2005; Parsons \& Beauchamp, 2012), and towards the Finnish mathematics education model in particular (Froese-Germain, 2010; Seaberg, 2015). There are no Qallunaaq university programs designed to equip Finnish mathematics teachers with skills to improve their communities.

One reason for this disparity is that the material contrast between Qallunaaq and Finnish communities, indicated by economic and demographic measures such as median income and common professions, is much less pronounced than the contrast between Qallunaaq and Inuit communities. In material terms, Qallunaat have less to offer Finns. But notwithstanding the fact that the responsibility for the material disadvantage of Inuit communities rests largely with Qallunaat, it is a fundamental error to mistake a material edge for a cultural one.

The first irony in the epigraph to this essay, the elder Apphia Kiliktee's recounting of her family's forced relocation to Pond Inlet, is how their relocation is announced: "A teacher came down to our camp and told us that we had to go to school" (Qikiqtani Inuit Association, 2013, p. 27). The sentence encapsulates a great deal: the premise of authority, the indifference of the directive, and above all, the teacher's assumption that "school" is a resource delivered from the South to the North. This is exactly the wrong way around.

\section{Centring the North}

In Canada, pedagogical assertiveness resides in the South, but the pedagogical advantage is in the North. The South has much to learn from the North-but care must be taken.

The history of Qallunaat acquiring things of value from the North is not a particularly happy one. It was the collapse of the fur trade that precipitated the forced settlement of Inuit in the first place (Marecic, 2000). More recently, the inequities of oil, gas and mineral extraction contributed to Nunavut surpassing Canada as a whole in per capita GDP, but also in rates of homelessness and substance abuse (Carlson, 2016). 
The Inuit pedagogical tradition is intrinsically valuable but extrinsically fragile. It requires protection, with Inuit as the primary instruments of protection. The territory of Nunavut itself provides a philosophical precedent: in the 1970s and 1980s, the Inuit Tapirisat of Canada and the Tungavik Federation of Nunavut proposed the territory in an attempt to claim a voice in discussions about Northern land use (Marecic, 2000). The same voice is indispensable in discussions about Northern education.

Inuit describe the main themes of Northern education in the 2007 document Inuit Qaujimajatuqanjit (Nunavut Department of Education, 2007). The document lists no authors, but its first acknowledgements name almost 80 elders, and a key passage states that "the knowledge of the Elders is the foundation which guides the lives of Inuit" (p. 25). The document is not a curriculum guide. Instead, it outlines the principles underpinning the Inuit educational model: eight Inuit Qaujimajatuqanjit (Inuit ways of knowing) precepts, as well as the maligait, atuagat and piqujat (respectively, natural, cultural and communal laws) that place the precepts in local context. It is a document that diminishes its own role in education, and returns authority to the land and the people.

The first step in protecting this approach is to recognize that it is, in a sense, untranslatable. The Inuit model is Inuit above all. Its insistence on the small and the local is likely perplexing to many in the South whose own education has been steeped in generations of logistical compromise. Squeezing the best practices of the North into a package for the South would miss the point entirely.

When Apphia Kiliktee's family were relocated into a tent in the Pond Inlet settlement, her grandfather built an iglu around it. A tent is of limited use where winter daytime temperatures are typically below $-30^{\circ} \mathrm{C}$. An iglu, on the other hand, provides good shelter from the cold and the wind. An iglu warmed only by body heat and a qulliq is as warm as an enclosed, heated house. Most important of all, an experienced builder can make one in a few hours using only the snow within a few steps of the site. The tent provided to Apphia Kiliktee's family may have been, in its way, a marvel of scale: built from canvas made with American cotton, to a template designed in England, and manufactured in bulk to be shipped across the Commonwealth. But the iglu makes sense.

We propose two practices. First, the makers of pedagogical iglus should be valued for their experience and expertise, should never be compelled to instruct others how to make iglus, and should never be made to call something an iglu which is not. There is a useful parallel in agriculture, in the appellation d'origine contrôlée geographical designation used in France to protect, for example, the craft and autonomy of winemakers in Beaune. The underlying principle is the French concept of terroir - the understanding that the land and generations of winemaking in Beaune combine to produce something distinctive and valuable. Inuit education has a definite terroir; indeed, it is nothing without terroir. Inuit educators should be the ones who control its description and dissemination, and government policies should support them. For example, no pedagogical changes should be made in a Northern community without the consultation and full agreement of Inuit in that community, according to guidelines enforced by the territorial and national governments. Suggestions from the community-for instance, that students be assigned instructors who follow them through the system, as opposed to in the Qallunaaq system, where students pass through the courses or years to which instructors are assigned-should be taken seriously; and if adopted, resourced properly. 
The second practice has to do with pedagogical change itself. As we argue above, Qallunaaq education has more to learn from Inuit education than the other way around. How should this learning occur?

The appellation d'origine contrôlée recognizing winemaking in Beaune stipulates that it is neither allowed, nor meaningful, to copy the techniques of the Beaune winemakers. Similarly, it should not be allowed, and it is certainly not meaningful, to copy wholesale the techniques of Inuit educators. What should be copied is the point of view. What does it mean in the Qallunaaq South to teach in deep context and in close relationships?

We should ask Inuit. Moreover, we should ask them like we ask the Finns: not with anthropological curiosity, but with a genuine recognition of excellence-and an additional understanding that the North owes nothing to the South. It is asking a great deal of librarians to lend books to people who tried to burn down the library.

Humble learning has disruptive consequences. For example, an authentic consideration of the Inuit model would diminish the emphasis on testability that colours so much of the current scholarship of mathematics teaching. Cutrara (2018) points out the clash of epistemologies in her essay "The Settler Grammar of Canadian History Curriculum": "[the Qallunaaq] understanding of the world must come from that which we can categorize and measure; if it does not, then it is not valid in our learning" (p. 261).

In sum, we propose to protect the North and to learn from it, and we propose that this must be done in a way that places Inuit in a position of strength.

\section{Tent Teaching in Calculus}

The crucial subtext is the weakness, upon review, of the Qallunaaq pedagogical position.

Every winter, thousands of students at Canadian universities learn about integrals. The integral is one of two central concepts in calculus, along with the derivative. Roughly speaking, it allows us to describe the area under a curve by adding up areas of thin cross-sections. As the cross-sections get thinner and the number of cross-sections gets larger, the approximations converge to the exact area under the curve. If the area is well-defined, the convergence point is the key: it will be the same regardless of the individual approximations, which are generally irrelevant.

Nevertheless, students also learn how to compute those approximations. There are multiple ways to do this, each with its own rule: the Left Endpoint Rule, the Right Endpoint Rule, the Midpoint Rule, the Trapezoid Rule, and Simpson's Rule. Each of the rules comes with its own error estimate, which answers the question, "How far off the actual area is the approximation?" A standard approach, which is used at the University of British Columbia, where I teach, is to derive one of the rules from scratch, and then simply to state the remaining rules and all of the error estimates as things to be memorized.

This is tent teaching. There may be excellent reasons to teach the approximation rules and error estimates; there certainly were, decades ago, before the wide availability of computing power. Stripped of context and handed out en masse, though, the approximation rules begin to look less like a lesson and more like a commercial product. 
The consequence is that many students take calculus, but few gain any significant conceptual understanding of it (Epstein, 2013). The product is consumed, and we are increasingly convinced that consumption - tents for everyone-is success. It is our good fortune that there are people who retain the resourcefulness needed to ignore the tent and build an iglu. We have a great deal to learn.

${ }^{1}$ While Qallunaaq simply means "non-Inuit" (the noun is Qallunaat), the implied meaning here, as in common usage, is "settler Canadian" or "settler North American."

${ }^{2}$ This testimony is translated from Inuktitut.

${ }^{3}$ WeBWorK is an online assessment tool that allows instructors to construct mathematics assignments using premade question banks.

${ }^{4}$ To be precise, consider the non-Sámi communities of Finland. There are multiple parallels between the Sámi experience in Finland and the Inuit experience in Canada. 


\section{References}

Aikenhead, G. S., \& Huntley, B. (1999). Teachers' views on Aboriginal students learning Western science. Canadian Journal of Native Education, 23, 159-176.

Alberta Education. (2012). Successful practices in First Nations, Métis and Inuit education. Edmonton.

Bligh, D. A. (1972). What's the use of lectures? Hertfordshire: New Barnet.

Bloom, H. (1986). James Boswell's Life of Samuel Johnson. New York: Chelsea House.

Carlson, J. (2016). Exploring the potential for achieving self-determined community economic development in Nunavut: An examination of the Government of Nunavut's economic development strategies. (Unpublished Masters dissertation). Lakehead University, Thunder Bay.

Chetty, R., Friedman, J. N., \& Rockoff, J. E. (2014). Measuring the impacts of teachers I: Evaluating bias in teacher value-added estimates. American Economic Review, 104(9), 2593-2632.

Cutrara, S. (2018). The settler grammar of Canadian History curriculum: Why historical thinking is unable to respond to the TRC's Calls to Action. Canadian Journal of Education, 41(1), $250-275$.

Duncan, H., \& Dick, T. (2000). Collaborative workshops and student academic performance in introductory College Mathematics courses: A study of a Treisman Model Math Excel Program. School Science and Mathematics, 100(7), 365-373.

Epstein, J. (2013). The calculus concept inventory: Measurement of the effect of teaching methodology in mathematics. Notices of the AMS, 60(8), 1018-1026.

Freeman, S., Eddy, S. L., McDonough, M., Smith, M. K., Okoroafor, N., Jordt, H., \& Wenderoth, M. P. (2014). Active learning increases student performance in science, engineering, and mathematics. PNAS, 111(23), 8410-8415.

Froese-Germain, B. (2010). The OECD, PISA and the impacts on educational policy. Ottawa: Canadian Teachers' Federation.

Gershenson, S. (2016) Linking teacher quality, student attendance, and student achievement. Education Finance and Policy, 11(2), 125-149.

Hill, H. C., Blazar, D., \& Lynch, K. (2015). Resources for teaching: Examining personal and institutional predictors of high-quality instruction. AERA Open, 1(4), 1-23.

Laghari, M. (2014). Automated Course Advising System. International Journal of Machine Learning and Computing, 4(1), 47-51.

Lombardi, M. (2005). Finland's education system is tops: Here's why. Teacher Newsmagazine, 17(5). Retrieved from web.uvic.ca/ gtreloar/Articles/Finland/

Marecic, C. J. (2000). Nunavut Territory: Aboriginal governing in the Canadian regime of governance. American Indian Law Review, 24(2), 275-295. 
Nunavut Department of Education (2007). Inuit Qaujimajatuqangit. Iqaluit: Nunavut Department of Education.

Oosten, J., \& Laugrand, F. (Eds.). (2017). Inuit worldviews. Iqaluit: Nunavut Arctic College Media.

Parsons, J., \& Beauchamp, L. (2012). From knowledge to action: Shaping the future of curriculum development in Alberta. Edmonton: Alberta Education.

Qikiqtani Inuit Association. (2013). Qikiqtani Truth Commission Thematic Reports and Special Studies 1950-1975: QTC Final Report: Achieving Saimaqatigiingniq. Iqaluit: Inhabit Media.

Seaberg, R. L. (2015). Mathematics lessons from Finland and Sweden. Mathematics Teacher, 108(8), 593-598.

Siegfried, R. M., Wittenstein, A. M., \& Sharma, T. (2003). An automated advising system for course selection and scheduling. Journal of Computing Sciences in Colleges, 18(3), 1725 .

Tajima, J. (1998). A study on the utilizations of small group learning in mathematics classroom: Mathematical problem solving by small group and metacognition. Journal of JASME: research in mathematics education, 4, 129-136.

Walczyk, J. J., \& Ramsey, L. L. (2003). Use of learner-centered instruction in college science and mathematics. Journal of Research in School Teaching, 40(6), 566-584.

Watters, A. (2015). The invented history of 'The Factory Model of Education'. Retrieved from http://hackeducation.com/2015/04/25/factory-model

Willinsky, J. (2018). The intellectual properties of learning: A prehistory from Saint Jerome to John Locke. Chicago: The University of Chicago Press. 